\title{
Vastos Cafezais e Grandes Dívidas: crédito hipotecário na formação da economia cafeeira em Ribeirão Preto (1876-1914)
}

\author{
Renato Leite Marcondes \\ Professor - Faculdade de Economia, Administração e Contabilidade de Ribeirão Preto (FEA/RP) \\ Endereço: Avenida Bandeirantes, 3900 - Monte Alegre - Ribeirão Preto/SP \\ CEP: 14040-905 - E-mail: rlmarcon@usp.br - http://orcid.org/0000-0002-7002-621X
}

Recebido: 03/08/2016. Aceite: 16/10/2017.

\section{Resumo}

A vasta estrutura produtiva cafeeira montada em Ribeirão Preto ao final do século XIX e início do XX contou com o apoio de empréstimos hipotecários. Grande parcela dos cafezais encontrava-se hipotecada nessa época. Os valores hipotecados superavam as transações imobiliárias do município. Grandes cafeicultores ou companhias agrícolas mantinham dívidas expressivas, apoiados em redes de parentesco ou de mesma nacionalidade. Apesar da importância do capital estrangeiro por meio das casas exportadoras e bancos, a maior parcela dos valores hipotecados estava nas mãos de pessoas e empresas paulistas.

\section{Palavras-Chave}

Hipoteca. Café. Crédito. Banco. Casas exportadoras.

\begin{abstract}
The great coffee production structure built in Ribeirão Preto in the late nineteenth century and early twentieth had the support of mortgage loans. Large share of the coffee plantations was mortgaged in this period. The mortgaged amounts exceeded the municipality's real estate transactions. Large farmers or agricultural companies held significant debts, based on kinship networks or the same nationality. Despite the importance of foreign capital through banks and export houses, the largest share of mortgaged values was in the hands of people and companies from São Paulo.
\end{abstract}

\section{Keywords}

Mortgage. Coffee. Credit. Bank. Export houses.

\section{JEL Classication}

N26.

- Agradeço o apoio da Fapesp (2007/00429-6) e do CNPq para a coleta e processamento das informações. Agradeço aos bolsistas Paulo Rogério Maduro Júnior, Lucas Sola Losa, Marcos Andrade Alves, Ulysses de Paiva Faleiros Neto e Victor Augusto de Almeida Oliveira.

(c) (i) (8) Esta obra está licenciada com uma Licença Creative Commons Atribuição-Não Comercial 4.0 Internacional. 


\section{Introdução}

O rápido avanço da cafeicultura para o nordeste do estado de São Paulo na bacia do rio Mogi Guaçu e Pardo ocorreu nas últimas décadas do século XIX. ${ }^{l}$ O cultivo contou com o auxílio da imigração de pessoas de outras regiões e países e o apoio das ferrovias, que buscavam as novas áreas cafeeiras. ${ }^{2}$ Dessa forma, as largas terras roxas favoráveis ao plantio tornaram-se disponíveis nessa região em contraste ao relevo mais estreito e acidentado do Vale do Paraíba entre a Serra do Mar e a da Mantiqueira, atraindo grande interesse para a região. ${ }^{3}$ A transformação acelerada de um território pouco cultivado em uma grande área cafeeira requereu investimentos consideráveis no último quartel do século XIX, tanto materiais como humanos. ${ }^{4}$ A mobilização dos capitais necessários não constituiu tarefa simples. Naquela época, já havia muitas reclamações dos agricultores sobre a falta de recursos para financiar a cafeicultura. ${ }^{5}$ A demanda elevada por recursos decorreu também do intervalo temporal de pelo menos quatro anos entre o momento de formação dos cafezais e o início da produção. Esses grandes investimentos cafeeiros propiciaram a liderança produtiva no início do século XX. O objetivo do presente artigo consiste em analisar os financiamentos hipotecários concedidos nessa área paulista, não apenas os seus movimentos ao longo do tempo e as condições dos empréstimos, mas também o perfil dos devedores e credores, compreendendo as pessoas e empresas locais, nacionais ou estrangeiras que atuaram nesse rush cafeeiro.

Diversos estudos discutem o financiamento para a cafeicultura em diferentes períodos e espaços. No caso do vale do Paraíba, a disponibilidade de recursos humanos e materiais em outras atividades preexistentes e regiões também facilitou, em face à ausência de bancos e de capital estrangeiro, a rápida expansão da cafeicultura nas primeiras décadas do século XIX, marcada no início pelas pequenas plantações. ${ }^{6}$ A lucratividade do cafeeiro

1 Ver Milliet (1939), Camargo (1952), Monbeig (1984) e Bacellar e Brioschi (1999).

2 Ver por exemplo Holloway (1984) e Saes (1981). Além de receber o apoio, o café também condicionou a imigração e o desenvolvimento ferroviário.

3 A imprensa divulgou vários relatos, demonstrando o interesse por essa região nos jornais da época. Já na A Província de São Paulo, de 15 de agosto de 1875, relatava a fertilidade das afamadas terras roxas na margem direita do rio Mogi: "no município de Ribeirão Preto, as terras que estão sendo cultivadas com grande vantagem..." (p. 2).

4 A população do município cresceu de 5.552 habitantes em 1874 para 12.033 em 1890, elevando a uma taxa média geométrica anual de 5\%. Isto salienta o grande fluxo migratório para a região.

5 Um fazendeiro de café fluminense apontou o longo tempo para o pagamento do financiamento, a impontualidade do devedor e a custosa e morosa justiça nas execuções como os principais fatores para as dificuldades de crédito dos cafeicultores no meado do século XIX (cf. Werneck 1857:15).

6 Stein (1961) e Motta \& Nozoe (1994). 
também permitiu o seu reinvestimento e atração de maiores cabedais, crescendo o tamanho dos plantios. Comerciantes, negociantes, capitalistas e comissários forneciam crédito, mas em geral a prazos curtos. O circuito de financiamento mostrava-se mais concentrado nas regiões produtoras desse momento, deixando papel mais secundário aos comerciantes e comissários dos principais centros econômicos, até mesmo o Rio de Janeiro. ${ }^{7}$ Apenas a partir da legislação hipotecária de 1846 e principalmente de 1864, os cafeicultores começaram a contar com crédito bancário mais direto, porém quase tão-somente a carteira hipotecária do Banco do Brasil criada em 1867, que concedia empréstimos a prazos maiores e juros mais favoráveis. ${ }^{8}$

O declínio da produtividade dos cafezais do vale do Paraíba também impulsionou a migração dos cafeicultores para novas áreas de cultivo, como a Caravana Pereira Barreto para a região de Ribeirão Preto. Somente a partir da década de 1880 os bancos de crédito real começaram a operar de forma mais ativa, apesar da legislação garantindo seus lucros ser de 1875, como o Banco de Crédito Real de São Paulo e Banco União de São Paulo. A política expansionista do Encilhamento também auxiliou em formas variadas de captação de recursos principalmente para companhias, como ações e debêntures. ${ }^{9}$ Uma intrincada rede de financiamento foi estabelecida para conseguir viabilizar os novos investimentos em grande monta nessa região ainda muito pouco desenvolvida em seus cultivos. A ampla necessidade de crédito para uma rápida expansão envolveu pessoas e empresas nacionais e de outros países, principalmente do Reino Unido. Para o período republicano, nota-se a presença mais atuante do capital bancário e estrangeiro, mesmo que de forma indireta por meio de intermediários locais. Por fim, os investimentos diretos do exterior também ocorreram por meio da compra de fazendas e companhias agrícolas. ${ }^{10} \mathrm{~A}$ historiografia salienta a participação de diferentes agentes locais, nacionais e estrangeiros no financiamento dos cafeicultores, mas ainda conhecemos pouco as participações efetivas desses atores nas regiões cafeeiras do Oeste de São Paulo. ${ }^{11}$

7 Sweigart (1980) e Marcondes (2002).

8 Ver Laerne (1885) e Piñeiro (2007).

9 Ver Saes (1986) e Hanley (2005).

10 Como veremos adiante o caso da Companhia Dumont (1896), mas existiram outros como a The São Paulo Coffee Estates Company Limited (1897) na região de São Simão e a Cambuhy Coffee and Cotton Estates Limited (1924) na região de Araraquara.

${ }^{11}$ Trabalhos mais recentes salientam o financiamento da cafeicultura no Oeste paulista, mas não a região de Ribeirão Preto: Teodoro (2006), Tosi, Faleiros e Fontanari (2011), Fontanari (2012), Faleiros (2014), Ribeiro (2015) e Fontanari (2016). Os estudos de Fontanari destacam-se por se basear em um conjunto amplo de hipotecas e penhores para a região de Casa Branca, que utilizaremos como comparativo mais adiante. 
Neste artigo, procuramos analisar a movimentação de recursos por meio do crédito hipotecário entre 1876 e 1914 para um município que se destacou na economia cafeeira: Ribeirão Preto. ${ }^{12} \mathrm{O}$ último quartel do século XIX foi a fase mais intensa de plantio para formar um estoque cafeeiro que atingiu cerca de trinta milhões de pés no início do século XX, representando um dos principais centros produtores do país nessa época. ${ }^{13} \mathrm{Na}$ segunda seção associamos o comportamento do crédito hipotecário ao mercado de compra e venda de imóveis do município. ${ }^{14}$ Também comparamos a dimensão e as condições dos empréstimos de Ribeirão aos negociados principalmente na capital paulista, permitindo uma melhor avaliação desses mercados. $\mathrm{Na}$ terceira seção, analisamos o perfil dos devedores do município, ressaltando o papel das grandes fazendas que se transformaram em companhias. $\mathrm{Na}$ quarta seção destacamos os credores, como os bancos e os intermediários locais, nacionais e estrangeiros. A quinta seção reservamos para considerações finais.

\section{Hipotecas na Expansão Cafeeira}

A expansão do crédito hipotecário foi bastante expressiva ao longo do último quartel do século XIX, acompanhando o avanço do plantio dos cafezais pela região. O apogeu dos valores negociados ocorreu em 1896, como pode ser visto no Gráfico 1. A partir da diminuição dos preços do café e da política contracionista de Murtinho, houve uma tendência de retração dos valores hipotecados. Os menores montantes transacionados

12 Para a discussão da formação da economia cafeeira em Ribeirão Preto ver Lopes (2005). A documentação encontra-se depositada no $1^{\circ}$ Cartório de Registro de Imóveis de Ribeirão Preto e, a partir de 1907, no $1^{\circ}$ Cartório de Registro de Imóveis de Sertãozinho, aos quais agradecemos pela disponibilização do acesso à documentação. No total analisamos pouco mais de três mil registros de hipotecas. Não incluímos na análise quatro casos de 1892 e dois de 1914 da Companhia Paulista por se tratar de empréstimos para o conjunto dessa companhia em diferentes cidades, que totalizaram quase sete milhões de libras.

13 Até 1906, as informações incluíram as hipotecas de Sertãozinho e Cravinhos, que pertenciam a comarca de Ribeirão Preto nessa época, sendo que a primeira se separou a partir dessa data. Se incluirmos os pés de café dessas duas cidades, chegaremos a um volume de quase 52 milhões de árvores e 3,5 milhões de arrobas em 1904-05, de acordo com a estatística agrícola e zootécnica desse ano.

${ }^{14}$ A documentação das escrituras de compra e venda de imóveis foi coletada por Jorge Caldeira nos livros de notas do $1^{\circ}$ Cartório de Notas de Ribeirão Preto e, de hipotecas, por Ana Luísa Montanari no $1^{\circ}$ Cartório de Registro de Imóveis de Sertãozinho, aos quais agradecemos ter disponibilizado esses dados para esta pesquisa. 
continuaram até o final da primeira década do século XX, mesmo depois do início da defesa do café em 1906. A reversão dessa tendência ocorreu parcialmente a partir de 1910. O novo pico dos negócios foi em 1912, mas inferior ao anterior. No conjunto do período, os valores hipotecados em Ribeirão Preto guardam uma correlação positiva e significativa com o preço implícito do café exportado em moeda nacional $(0,44) .{ }^{15}$ De outro lado, também há uma correlação semelhante com o estoque de moeda (M1), que atingiu 0,65. ${ }^{16}$ Assim, o movimento das hipotecas em Ribeirão Preto mostrou-se correlacionado ao dos mercados cafeeiro e monetário do país. No todo, levantamos um conjunto de pouco mais de três mil hipotecas, que somaram quase duzentos mil contos de réis.

Como já esperado, a dinâmica hipotecária revelou-se semelhante à movimentação de aquisição de imóveis. ${ }^{17}$ No período como um todo, a correlação entre as duas variáveis mostrou-se significativa, chegando a 0,47. Todavia, esse valor mostrou-se mais reduzido do que o verificado para a cidade de São Paulo em período um pouco posterior. ${ }^{18}$ Ademais, em termos absolutos, notamos para a capital poucos anos que os valores das hipotecas superaram os das escrituras, mas em Ribeirão ocorreu sistematicamente de 1888 a 1914. O descompasso entre os dois valores no período republicano apontou, provavelmente, a utilização dos recursos não mais para aquisição de imóveis, mas principalmente para investimento, financiamento da safra ou, até mesmo, refinanciamento de empréstimos anteriores. ${ }^{19}$

${ }^{15}$ Conforme estatística publicada pelo IBGE (1990, p. 350).

${ }^{16}$ Conforme a série construída por Peláez \& Suzigan (1981, p. 399-405). Como seria esperado, o preço do café e o estoque de moeda também são correlacionados.

${ }^{17} \mathrm{O}$ movimento de aquisições de imóveis condicionou, fortemente, o crédito hipotecário e foi condicionado por ele. A hipoteca consistia da mais importante forma de financiamento para a compra de imóveis, que passaram a ser a principal garantia desses empréstimos na época.

18 Para as escrituras de compra e hipotecas paulistanas verificamos uma correlação muito elevada entre 1912 e $1928(0,93)$, demonstrando uma grande associação entre os dois mercados. Na média, a proporção de hipotecas em comparação às escrituras foi de $82,6 \%$. Um descompasso maior ocorreu em 1914 , quando as hipotecas representaram $254,6 \%$.

${ }^{19}$ Uma parcela da diferença decorreu provavelmente da separação dos municípios de Sertãozinho e Cravinhos que ocorreu primeiro nas escrituras de imóveis do cartório de notas do que nas hipotecas do cartório de registro de imóveis. Como não dispomos das escrituras de compra e venda de imóveis de Sertãozinho, no Gráfico 1 não incluímos as hipotecas de Sertãozinho posteriores a 1907. 


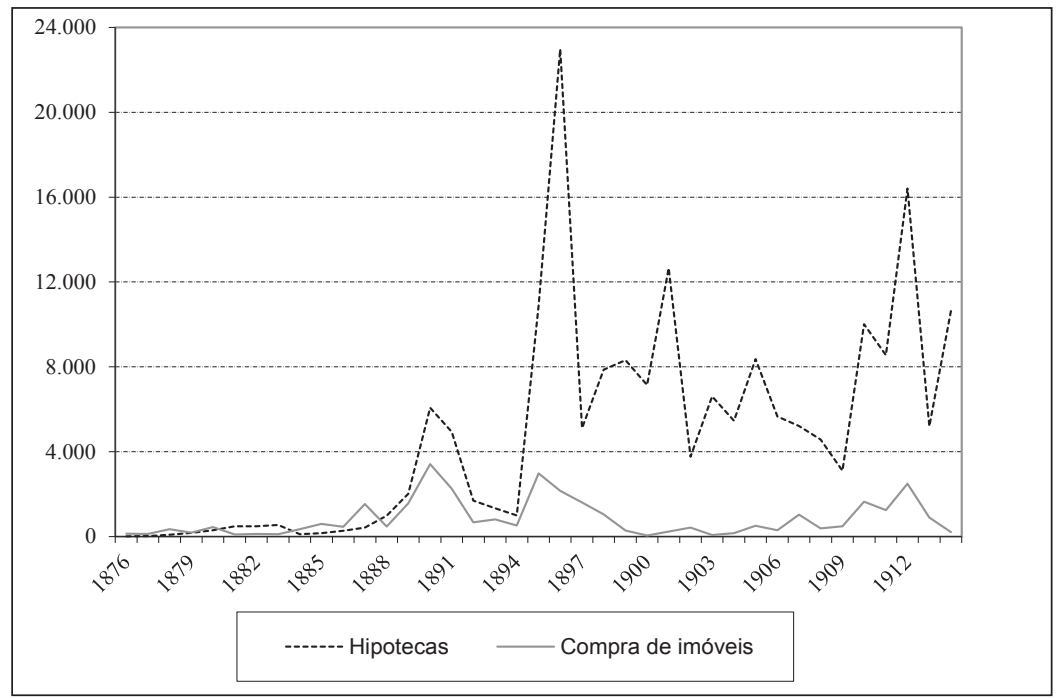

Gráfico 1 - Crédito hipotecário e compras de imóveis em Ribeirão Preto (1876-1914) (valores constantes em contos de réis de 1913)

O crédito hipotecário revelou-se fortemente associado à compra de imóveis até o final do Império, pois observamos uma paridade muita próxima entre os montantes negociados em hipotecas e imóveis na década de 1880 . A partir do Encilhamento, o financiamento por meio de hipotecas dinamizou-se muito mais do que as compras e vendas de imóveis no município. Novos instrumentos e atores financeiros facilitaram o fornecimento de crédito para as áreas de expansão cafeeira, como veremos adiante. Os valores transacionados nas hipotecas representaram 4,5 vezes os de imóveis na década de 1890, e chegaram a 17,4 vezes na primeira do século XX. Desse modo, há evidência de um grande boom de crédito hipotecário em Ribeirão Preto nesse momento. Contudo, a partir do final da primeira década inicial do século XX houve uma reaproximação das duas séries, apontando para uma nova trajetória de proximidade entre crédito e aquisição imobiliária, mas ainda movimentou 7,8 vezes nos primeiros anos da década de 1910 . Possivelmente, os investimentos nas propriedades agrícolas retraíram-se nesse último período, estabilizando o número de cafezais plantados no município.

No conjunto do período em análise, a movimentação hipotecária superou amplamente o transacionado na compra e venda de imóveis no município, diferentemente da capital paulista que se mostraram mais próximos. 
Se compararmos apenas as hipotecas de Ribeirão Preto com as paulistanas podemos avaliar de melhor modo a importância relativa e o comportamento mais geral e específico dessa primeira praça, ou seja, não resultante da conjuntura mais geral da economia brasileira ou paulista. Em termos de número e principalmente valor das hipotecas, verificamos uma elevada representatividade das transações de Ribeirão Preto relativamente às da capital paulista no período em questão, apesar de ele ser um município relativamente mais recente e muito menos populoso. Ribeirão realizou menos de um décimo das hipotecas paulistanas $(8,4 \%)$, mas transacionou pouco mais de um quinto dos valores da segunda $(21,5 \%)$. Os valores médios foram muito superiores em Ribeirão, em função da maior quantia envolvida numa única propriedade agrícola do que a propriedade média da urbe paulistana. Se analisarmos a expressiva desigualdade dos valores negociados entre 1876 e 1914, verificaremos um índice de concentração de Gini de 0,867 para Ribeirão enquanto na capital paulista foi de $0,832 .^{20}$ Não obstante o município começar a se destacar no cultivo do café e a capital paulista como um grande centro urbano, concentrando atividades comerciais, administrativas e industriais, observamos, no geral dos movimentos das duas séries, uma tendência de crescimento mais próxima tanto em termos do número de hipotecas (correlação de 0,77 ) como dos valores das duas praças $(0,47)$. A economia cafeeira compreendeu outras atividades, que apresentavam tendências gerais semelhantes em diferentes espaços econômicos.

Quando analisamos anualmente a participação de Ribeirão Preto nos montantes da capital paulista, notamos conjunturas específicas da primeira, como pode ser observado no Gráfico 2. Um primeiro crescimento relativamente expressivo das hipotecas de Ribeirão ocorreu nos anos anteriores à chegada da ferrovia e sua estação, que foi inaugurada ao final de 1883. Houve também uma tendência de aumentar a representatividade de Ribeirão naquele movimento febril do Encilhamento, mas principalmente já ao final do século XIX. Entre 1895 e 1900, o número de hipotecas de Ribeirão superou um décimo da capital e os valores atingiram mais da metade do total paulistano em vários desses anos. Em 1896, os valores transacionados em Ribeirão ultrapassou o das hipotecas paulistanas, destacando negócios extraordinários que reportaremos na próxima seção. Assim, o município paulista apresentou um boom de crédito hipotecário

\footnotetext{
${ }^{20}$ Não consideramos nesse cálculo a repetição de nomes que ocorreu com frequência para os credores, principalmente na capital paulista. Podemos imaginar que se isto for considerado a concentração seria ainda maior.
} 
nos primeiros anos da República mais intenso do que o movimento paulistano, salientando ser próprio da sua realidade específica. Todas essas comparações reforçam os momentos diferenciados vivenciados por Ribeirão Preto em face aos grandes investimentos nas propriedades cafeeiras, como veremos adiante.

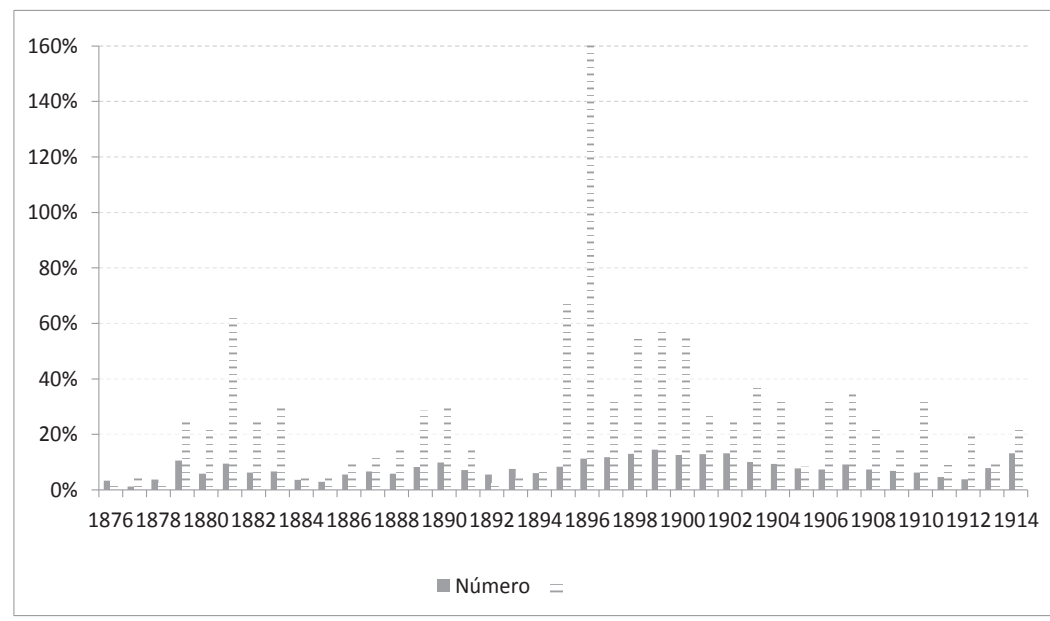

Gráfico 2 - Participação de Ribeirão Preto nas hipotecas de São Paulo

Selecionamos o período 1896-1914, em função de conseguirmos informações de outros municípios. Ribeirão Preto registrou 168 mil contos de réis em hipotecas, mas a capital paulista atingiu 654 mil contos. ${ }^{21}$ Em relação a outros municípios cafeeiros, notamos um montante transacionado de 24 mil contos em Casa Branca (cf. Fontanari 2012: 97) e de 21 mil contos em Juiz de Fora (cf. Pires 2009). De outro lado, os penhores no município de Ribeirão Preto somaram pouco mais de 23 mil contos de 1896 a 1914 (cf. Lavaez 2017: 14), revelando uma fonte relevante de financiamento. Em Casa Branca, os valores dos penhores agrícolas atingiram pouco mais de dez mil contos em idêntico período (cf. Fontanari 2012: 98). Assim, a região de Ribeirão Preto apresentou uma movimentação de valores muito acima de outras localidades cafeeiras, acompanhando os grandes montantes produzidos de café. O rush cafeeiro necessitou de uma ampla soma de recursos para a rápida ocupação do território, decorrentes de financiamentos

${ }^{21}$ O Distrito Federal deve ter negociado um valor um pouco maior do que a capital paulista em idêntico período, pois falta a informação para 1910 a 1912 (ver Anuário Estatístico do Brasil de 1909:197, e de 1939/1940:1349-1351). 
principalmente hipotecários, mas também de penhores e de outras formas. As companhias para levantar capital lançaram ações, debêntures etc., como veremos na próxima seção.

Além dos valores, podemos comparar as condições dos empréstimos. As taxas de juros em Ribeirão Preto e São Paulo apresentaram, como podemos observar no Gráfico 3, uma tendência de redução de 1878 até o início do Encilhamento, crescendo ao final do século XIX. ${ }^{22}$ No início do século $\mathrm{XX}$, houve uma lenta redução de taxas, revertida nos dois últimos anos em análise. Após uma grande oscilação das taxas no início do período para Ribeirão, quando temos menor número de informações, os movimentos das duas localidades foram próximos, mas mantiveram patamares distintos. ${ }^{23}$ Essa última apresentou, regularmente, as maiores taxas, provavelmente em virtude da elevada demanda relativamente à oferta de crédito. São Paulo oscilou muito menos, talvez em função do grande número de transações, mantendo juros menores. ${ }^{24}$ Destarte, as correlações foram significativas entre as cidades $(0,59)$, não obstante patamares distintos. As taxas de juros dos empréstimos com seus movimentos relativamente próximos apontaram para a existência de arbitragem entre as praças.

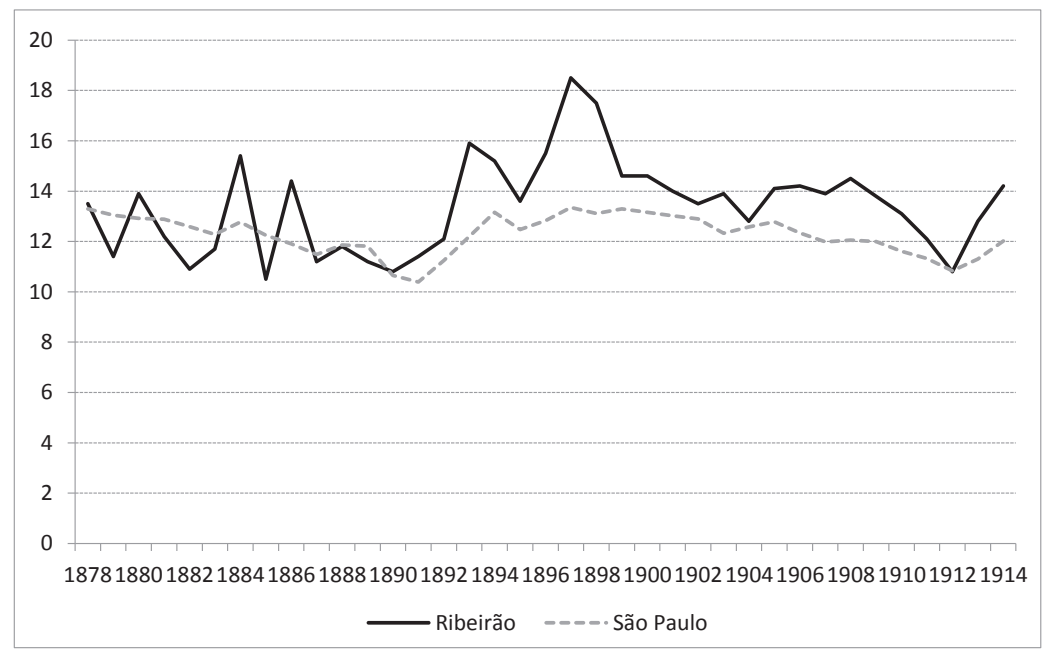

Gráfico 3 - Taxas de juros médias anuais de diferentes localidades (em \%)

\footnotetext{
${ }^{22}$ Não utilizamos os dois primeiros anos da série de juros e prazos por conta do reduzido número de observações.

${ }^{23}$ Quando testamos a igualdade das médias de taxas de juros rejeitamos a hipótese para o conjunto do período de 1878 a 1914.

$24 \mathrm{O}$ coeficiente de variação dos juros médios da capital paulista foi o menor comparativamente $(0,27)$, enquanto que Ribeirão atingiu $(0,50)$.
} 
A variação dos prazos revelou-se muito mais elevada do que a dos juros, não apenas as grandes oscilações no início da série de Ribeirão, como visto no Gráfico 4. Verificamos coeficientes de variação muito superiores para os prazos do que os juros. Como ocorreu com relação aos juros, os prazos médios foram menores para a capital paulista. ${ }^{25}$ As correlações entre as localidades não foram significativas, salientando movimentos anuais distintos entre elas. ${ }^{26}$ Houve uma convergência maior dos prazos a partir da década de 1890, principalmente das paulistas. No período de grande investimento em Ribeirão, os patamares dos prazos médios mostraram-se muito semelhantes aos de São Paulo, ao contrário dos juros que foram maiores. Apesar de não haver correlação entre as séries, o patamar dos prazos médios próximos e a grande variabilidade delas impossibilitou a diferenciação dos prazos médios. ${ }^{27}$

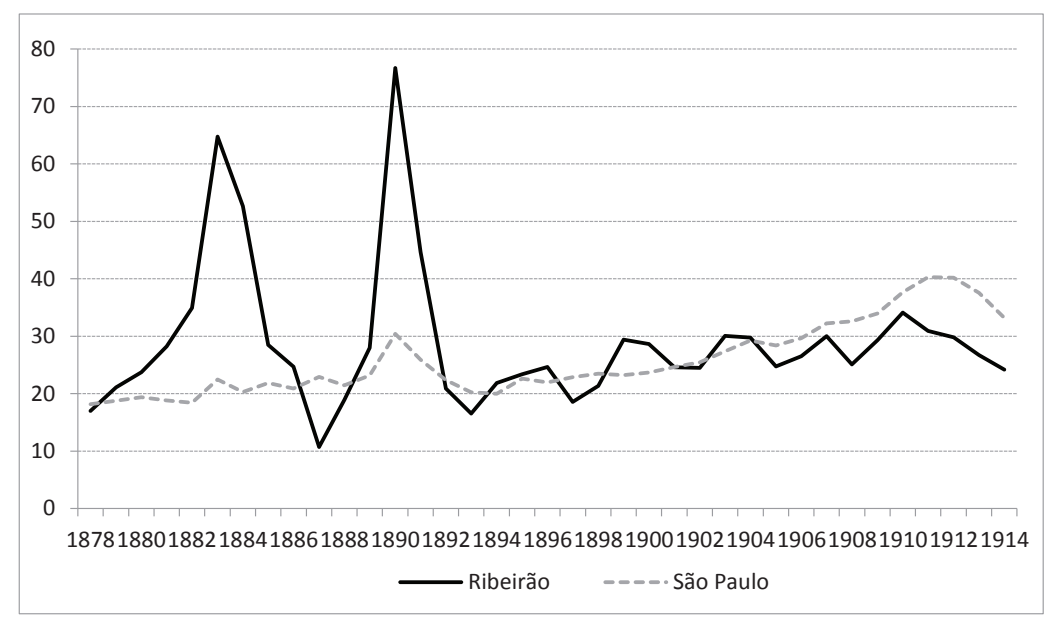

Gráfico 4 - Prazo médio de diferentes localidades (em meses)

Os imóveis fornecidos em garantia foram tanto rurais como urbanos, apresentando os primeiros uma ligeira maioria $(52,8 \%)$. Se considerarmos o período de 1876 a 1906, verificamos uma participação rural ainda maior $(60,0 \%)$, revelando o maior dinamismo urbano ao final do período.

${ }^{25} \mathrm{O}$ coeficiente de variação do prazo médio da capital paulista foi o menor comparativamente $(0,78)$, enquanto que Ribeirão atingiu $(1,25)$.

${ }^{26}$ A correlação do prazo médio anual de Ribeirão e São Paulo chegou a apenas 0,13.

27 Quando testamos a igualdade das médias de prazos aceitamos a hipótese para o conjunto do período de 1878 a 1914. 
Em termos de valores, a preeminência do rural revelou-se muito superior, chegando a nove décimos do total negociado em todo o período $(91,0 \%)$. A presença de cafezais mostrou-se expressiva nos rurais, que estavam presentes em cerca de três quartos dessas transações $(73,1 \%) .{ }^{28} \mathrm{O}$ número médio de pés de café por hipoteca rural que apresentava a informação chegou a 118 mil. De outro lado, a área média hipotecada de propriedades rurais com ou sem café atingiu 240 alqueires paulistas, referente a pouco mais de mil e duzentos casos. Destarte, o tamanho médio das garantias rurais demonstrava-se bastante expressivo.

Nos primeiros anos em análise, verificamos a presença de escravos como colateral, que muitas vezes era preferido pela sua maior liquidez do que o imóvel rural. De 1876 até 1887, anotamos 43 plantéis nas hipotecas, compreendendo 525 cativos. O maior número deles foi empregado no ano de 1883, quando alcançou 134 pessoas. Nesse ano, Luiz Antonio Junqueira hipotecou ao Banco de Crédito Real de São Paulo o maior plantel lançado como colateral, compreendendo 55 indivíduos. ${ }^{29}$

O montante de cafezais e de alqueires anualmente dado em garantia das hipotecas apresentou uma forte correlação com os montantes dos empréstimos. ${ }^{30}$ Entre 1888 e 1890, verificamos dezenas de milhares de alqueires garantindo os financiamentos e, posteriormente, vários milhões de pés de café também foram adicionados como colateral. Como o prazo médio dos empréstimos rurais foi de 2,6 anos, podemos supor que o fluxo de 11 milhões de pés hipotecados em 1904 e 1905 representasse pouco mais de um quinto do estoque de pés existentes no município no recenseamento de 1904-05 (21,7\%). Assim, uma parte expressiva dos cafezais era hipotecada a cada ano, demonstrando a relevância desse instrumento financeiro para o funcionamento da economia cafeeira em Ribeirão.

Os volumes extraordinários de hipotecas em Ribeirão Preto relativamente aos negócios de imóveis e até mesmo às paulistanas demonstram também a existência de um boom de crédito na região, principalmente ao final do século XIX e início do XX. O mercado de crédito mostrou-se integrado entre diferentes localidades, apresentando movimentos e patamares se-

${ }^{28}$ Em alguns casos não há a descrição do cultivo na propriedade que garante a hipoteca, incluindo casos de chácaras. Entre as outras atividades agrícolas não cafeeiras destacou-se a cana-de-açúcar, compreendendo canaviais e engenho.

${ }^{29}$ Entre os escravos havia 25 matriculados em diferentes municípios do Nordeste e cinco em Minas Gerais.

${ }^{30}$ A correlação entre número de cafezais e de alqueires foi de 0,64 entre 1879 e 1914 e do primeiro com o valor real chegou a 0,77 . 
melhantes das condições dos empréstimos na maior parte do período em estudo. A expansão do cultivo do cafeeiro demandou crédito e incentivou a entrada de capitais de diferentes origens. Os montantes expressivos decorreram, pelo menos em parte, de empréstimos hipotecários de grandes fazendas de café em montantes substantivos. ${ }^{31}$ Agora, precisamos conhecer os principais atores nesse mercado, tanto devedores como credores.

\section{Grandes Devedores: de grandes cafeicultores a companhias agrícolas}

Numa primeira visão mais geral, analisamos o perfil agregado dos devedores, de acordo com a ocupação e moradia. Inicialmente, em termos do número deles, quase a metade eram lavradores ou fazendeiros $(47,5 \%)$, mas ainda existia uma parcela significativa de proprietários $(27,2 \%)$ e negociantes $(14,0 \%) .{ }^{32}$ Segundo, quando consideramos a participação nos valores reais, os lavradores ou fazendeiros passaram a movimentar quatro quintos dos montantes negociados $(80,3 \%)$ e os proprietários pouco mais de um décimo $(11,0 \%)$. Apesar de ser um município recente, a moradia dos devedores concentrou-se em Ribeirão Preto, em termos do número de hipotecas $(84,1 \%)$. Ademais, ainda havia parcela significativa para o interior de São Paulo $(10,3 \%)$ e a capital paulista $(4,5 \%)$. Por outro lado, os valores também se concentraram em Ribeirão, mas em proporção muito menor $(49,6 \%)$, pois a capital paulista elevou sua representação $(39,0 \%)$. Assim, a grande maioria dos fazendeiros e lavradores declarava-se residência no município. ${ }^{33}$

O boom de crédito hipotecário em Ribeirão Preto pode ser observado pela movimentação de hipotecas em montantes superiores às compras de imóveis, comparáveis mesmo às da capital paulista em vários anos. Grande parte desses financiamentos foi negociada por grandes fazendeiros. As dezoito hipotecas compreendendo propriedades com pelo menos um milhão

${ }^{31}$ Colistete \& Lamounier (2014, p. 14-15) verificaram a maior proporção de grandes propriedades (latifúndios) no território do Nordeste paulista para a região de Ribeirão Preto, perfazendo $64,6 \%$ da área em relação a 52,6\% para todo o Nordeste paulista. Ribeirão ainda mantinha o maior grau de desigualdade da posse da terra (Gini de 0,838 e 0,773, respectivamente), porém não da terra cultivada ou dos pés de café.

32 Devemos salientar que a designação proprietário pouco informa sobre a profissão do devedor de uma hipoteca.

${ }^{33}$ Quatro quintos do total deles moravam em Ribeirão Preto (80,7\%). 
de pés de café, responderam por pouco mais de um quarto dos pés de café ou um quarto dos valores reais $(27,2 \%)$. Esses volumes extraordinários permitiram a expansão de suas propriedades e de seus cafezais. A maior parte delas transformou-se em companhia agrícola para facilitar a administração e sucessão nos negócios, seja por venda ou herdeiros. Entre a totalidade dos devedores com garantia de imóveis rurais verificamos a presença de quase um décimo de companhias $(8,7 \%)$, bastante superior ao porcentual dos devedores urbanos. Destacamos os principais casos a seguir como forma de ilustrar a importância desses agentes.

Henrique Dumont foi um grande cafeicultor de Ribeirão Preto e pioneiro na plantação em larga escala com a utilização de máquinas de beneficiamento do café. A primeira aquisição no município foi a grande fazenda Arindeúva, escriturada em setembro de 1880 e o pagamento em duas parcelas: 70 contos de réis a vista e 50 contos em um ano. ${ }^{34} \mathrm{~A}$ primeira hipoteca em seu nome ocorreu em agosto de 1881, no valor de 45 contos de réis, quando vencia a segunda parcela do pagamento do sítio. A garantia da hipoteca foi a fazenda com cafezais e 16 escravos matriculados em Minas Gerias, de onde provinha. O prazo de pagamento foi de 4 anos, porém, somente foi quitada em 1889. Dumont houve por compra mais nove propriedades nos dez anos seguintes, perfazendo um total de 377,4 contos de réis. ${ }^{35}$ Não obstante as várias aquisições, houve apenas mais uma hipoteca em 1888, alcançando o valor de 80 contos de réis e quitada em 1890. Até essa época, as hipotecas não se descolaram do movimento de aquisições de propriedades, pelo contrário, eram em montante menor do que as compras revelando a possibilidade da existência de capital acumulado. ${ }^{36}$

Os financiamentos cresceram quando da criação da Companhia Agrícola da Fazenda Dumont em 1890, constituindo um capital de 5.392 contos subdividido em 26.961 ações de $200 \$ 000$ réis. Ela realizou ainda nesse ano um empréstimo hipotecário com o Banco União de São Paulo no valor de 500 contos por 30 anos e juros de $6 \%$ ao ano. A garantia foi a Fazenda Dumont, que era uma grande propriedade rural com cerca de ${ }^{7}$ mil alqueires e ${ }^{2}$ milhões de pés de café. A companhia adquiriu oito propriedades entre ${ }^{1890}$ e 1895, porém em quantias bastante reduzidas, que somaram pouco me-

\footnotetext{
${ }^{34}$ O sítio foi adquirido de José Bento Diniz Junqueira, segundo o livro de notas número 12 do Cartório de Notas de Ribeirão Preto.

35 Ele fez parte da criação do Club da Imigração, Lavoura e Comércio em 1884, que combatia a propaganda abolicionista e apoiava a imigração estrangeira.

36 De acordo com Silvio Zamboni: "As compras feitas por Henrique Dumont, por volta de 1880, foram possíveis devido às suas economias próprias e à herança deixada pelo sogro (...)” (1979: 15).
} 
nos de cinquenta contos de réis. Ainda em 1891, a companhia incorporou a Fazenda Albertina pertencente a Martinho Prado Júnior, que recebeu 12.250 ações, alcançando o capital da companhia a 8.500 contos de réis. Assim, a incorporação não necessitou de financiamento.

Os maiores valores negociados em toda a pesquisa com hipotecas de Ribeirão Preto foram duas emissões de debêntures pela Companhia Dumont, que hipotecou a fazenda, cafezais e demais benfeitorias, inclusive o ramal ferroviário. ${ }^{37} \mathrm{O}$ primeiro empréstimo começou a ser negociado ao final de 1890 e registrado em 1895, e alcançou 8 mil contos de réis a juros de 6\% ao ano, sendo credora a Empresa Industrial Melhoramentos e os debenturistas. ${ }^{38}$ Essa última companhia assumiu o controle da companhia em 1891, mantendo a quase totalidade das ações. ${ }^{39}$ Nesse ano, o relatório e balanço da companhia foram bastante favoráveis:

O produto da safra de 1891 foi pois superior a 2.308 contos e tendo sido de 312:873\$770 todas as despesas com tratamento, colheita, benefício e transporte desse café, vê-se que é de mais de 1.995 contos, a renda líquida da safra de 1891, que, além de ter sido relativamente grande, alcançou bons preços. (Correio Paulistano, 30 de março de 1892:3).

Da receita de 2 mil contos, boa parte ainda estava por vender, que se esperava por bom preço, acima do previsto no balanço. O bom resultado da safra permitiu o pagamento de dividendos generosos de $22,5 \%$ do valor da ação nesse primeiro ano, consumindo quase toda a renda líquida da companhia. Posteriormente, os dividendos foram suspensos em proveito da expansão e renovação dos cafezais. Em 1895, retornou o pagamento de $8,5 \%$ do valor da ação.

Em 1896, houve uma ampla reorganização societária da empresa, que foi vendida por 1,2 milhões de libras esterlinas, que ao câmbio de 10 dinheiros chegou a 28,8 mil contos de réis. Ela transformou-se Dumont Coffee State

${ }^{37}$ A hipoteca de 1896 compreendeu a Fazenda Dumont com todas as suas terras e benfeitorias existentes; 4.426.604 pés de café de diversas idades, pastos, máquinas de beneficiar café, ramal férreo Dumont, tronco e ramais com 4 estações, 4 locomotivas, vagões e trilhos.

${ }^{38}$ No balanço referente a 1891, o capital declarado da companhia era de 8,5 mil contos e o saldo passivo em debêntures de quase oito mil contos (cf. Correio Paulistano, 30 de março de 1892: 3). A contratação do empréstimo baseado em debêntures foi firmada ao final de 1890.

${ }^{39}$ Diário Oficial de São Paulo, 7 de abril de 1892:2528. 
Company com ações em Londres no total 800 mil libras de capital. Para substituir o empréstimo anterior, a companhia Dumont lançou debêntures em Londres no valor de 400 mil libras (cerca de 11.334 contos) a juros de 5,5\% ao ano. ${ }^{40}$ Ademais, a companhia ainda tomou um empréstimo hipotecário de cerca de 250 mil libras com negociantes de Londres nesse ano de 1896, que seria pago em 24 anos. Essas três últimas hipotecas da companhia Dumont totalizaram mais de 26,86 mil contos. Os grandes empréstimos não se traduziram em novas aquisições de propriedades, mas o fechamento da operação de aquisição. A troca do controle não levou a resultados iniciais favoráveis, como eram esperados ou até prometidos. Isto se refletiu na não distribuição de dividendos nesses primeiros anos de 1897 a 1899, por conta da redução das safras e dos preços do café e até um incêndio. A situação da companhia melhorou aos poucos, já apresentando saldo líquido positivo acima de mil contos na maioria dos exercícios de 1899 a $1912 .^{41}$ Desse modo, a companhia gerou lucros substantivos para seus acionistas, por meio de dividendos. ${ }^{42}$

A companhia detinha, em 1904-05, doze mil alqueires de terras e quatro milhões de pés de café. As dívidas declaradas em seus balanços foram quase que exclusivamente por debêntures, representando o financiamento por contas correntes parcela muito reduzida. Como podemos analisar a partir do balanço de 1907, o empréstimo por debêntures perfez $21,5 \%$ do passivo total da empresa. As demais dívidas por conta corrente eram muito reduzidas relativamente ao patrimônio. ${ }^{43}$ Dez anos mais tarde, os valores lançados eram muito semelhantes aos de 1907, demonstrando uma realidade ou uma contabilidade sem mudanças, apesar das variações cambiais da libra. ${ }^{44}$

40 O Estado de São Paulo, 7 de outubro de 1896:1.

41 Ver The Brazilian Review de 5 de junho de 1900 (p. 365) e de 7 de agosto de 1906 (p. 707) e Diário Oficial de 28 de maio de 1901 (p. 1464), de 1 de julho de 1902 (p. 1399), de 28 de junho de 1904 (p. 1224).

42 A companhia Dumont mostrou-se lucrativa e pagou regularmente dividendos de 1907 a 1913, ver Bill \& Henderson (2002:83-85).

${ }^{43}$ Diário Oficial de São Paulo, 6 de maio de 1908:1780. Havia um débito de pouco mais de mil e seiscentos contos com a própria The Dumont Coffee Company Limited. Mesmo no balanço de 1918 em libras publicado no Wileman's Brazilian Review (24 de setembro de 1919:374), também apontava apenas a dívida por debêntures e não havia o débito com a The Dumont Coffee.

${ }^{44}$ Diário Oficial de São Paulo, 13 de junho de 1918, p. 3220. Ainda persistia o débito com a Dumont Coffee, mas com um valor menor. Posteriormente, há uma redução ainda maior, mas há uma dívida com o London and Brazilian Bank. De toda a forma, as dívidas são reduzidas relativamente ao patrimônio. 
Outro caso emblemático da época foi do alemão Francisco Schmidt, que se tornou o maior fazendeiro paulista no início do século $\mathrm{XX}{ }^{45}$ Ele adquiriu um extraordinário volume de propriedades de 1890 a 1912, totalizando 50 imóveis e pouco mais de cinco mil contos de réis apenas em Ribeirão Preto. De outro lado, efetuou treze hipotecas de 1889 a 1910, somando quase dezenove mil contos de réis. ${ }^{46}$ Seis hipotecas foram realizadas com a Theodor Wille, que era uma grande casa exportadora alemã de café. Essas últimas dívidas corresponderam a pouco mais de dezessete mil contos, ou seja, a principal fonte de financiamento para Schmidt (91,5\% do total). A garantia compreendeu treze fazendas. Assim, esse fazendeiro demonstrou uma elevada associação com essa empresa, conseguindo possivelmente condições mais favoráveis nos empréstimos e na comercialização do café. Por outro lado, a empresa deveria ter exclusividade da comercialização do seu café. $^{47}$

No conjunto de suas fazendas em Ribeirão Preto e Sertãozinho, ele possuía dez mil alqueires de terras e seis milhões de pés de café em 1904-05. ${ }^{48}$ Desse modo, também nesse caso verificamos um descompasso entre as aquisições e os financiamentos bastante expressivo, embora um pouco menor do que o caso anterior. Em 1917, organizou-se a Companhia Agrícola Francisco Schmidt, com sede social em São Paulo. No relatório do ano seguinte a companhia apontava a grande geada de 1918 como responsável pelas dificuldades, além da perda de pessoal pela gripe espanhola. ${ }^{49}$ Desse modo, a companhia procurou diversificar as suas atividades, incrementando a criação de gado e a exploração da cana e algodão. No balanço desse ano, os empréstimos respondiam por cerca de dois terços do passivo total da companhia, sendo apenas os garantidos por hipotecas quase equivalente ao capital integralizado e representando um quarto do passivo. Além das hipotecárias, a companhia detinha dívidas garantidas por warrants, penhor agrícola e mercantil e nas fazendas, com colonos, empreiteiros, empregados e fornecedores. ${ }^{50}$ Não há menção ao pagamento de dividendos aos acionis-

\footnotetext{
${ }^{45}$ Ver Moraes (1980) e Forner (2017).

${ }^{46}$ A primeira hipoteca foi anterior à compra em virtude de a propriedade ser em Serra Azul, distrito de São Simão.

${ }^{47}$ Maria Luiza de Paiva Melo Moares ao analisar os negócios da companhia Theodor Wille verificou que "passou a ter o controle total sobre a produção cafeeira de Schmidt." (1988, p. 103). Além de relatórios detalhados por fazenda com situação do cultivo, produção e dos custos, a firma realizava visitas regulares as fazendas.

${ }^{48}$ Em relatório posterior há a informação de propriedades fora desses dois municípios, porém não informam quais.

${ }^{49}$ Ver Correio Paulistano de 10 de maio de 1919 (p. 5).

${ }^{50}$ Em 1921, a companhia fez um grande empréstimo de 750 mil libras com o Banco Frances e Italiano e a Brazilian Warrants por meio de debêntures (cf. A Noite, 15 de março de 1921:3).
} 
tas. Na década seguinte a companhia entrou em liquidação, vendendo grande parcela das suas propriedades para pagamento das dívidas.

Martinho da Silva Prado Júnior comprou a fazenda Guatapará em 1885, a qual atingirá cerca de seis mil alqueires de terras e dois milhões de pés de café em 1904-05. ${ }^{51}$ Ocorreram várias aquisições de propriedades entre 1879 e 1889, perfazendo pouco mais de 62 contos. Contudo, a primeira hipoteca foi apenas em 1896, que totalizou quase mil contos de réis com a Theodor Wille. A hipótese levantada por Darrel Levi foi de que com recursos emprestados pelo pai não houve a necessidade de financiamento anterior (1977:167). Somente dez anos mais tarde, a viúva fez um empréstimo hipotecário de 2.500 contos de réis com o Banco de Comércio e Indústria de São Paulo, sendo que a garantia foi avaliada em 3.300 contos. $^{52}$ Quando da transferência da fazenda para os filhos em 1912 criou-se a companhia Guatapará com sede em São Paulo, totalizando um capital de 5 mil contos de réis. ${ }^{53}$ No balanço desse ano não foi anotada nenhuma dívida da empresa, apenas dividendos a distribuir e impostos a pagar. Os dois primeiros dividendos foram a razão de $12 \%$ e o terceiro a $8 \%$, totalizando mil contos em pagamentos. Esse padrão de distribuição de dividendos manteve-se nos anos seguintes. Desse modo, a situação dessa empresa mostrava-se claro contraste com a situação da Schmidt. ${ }^{54}$

A família Prado ainda adquiriu a fazenda São Martinho em 1889, que recebeu vários financiamentos sucessivos. ${ }^{55}$ A primeira hipoteca também foi com a Theodor Wille em 1896, como a outra Guatapará. A fazenda consistia numa propriedade de doze mil alqueires e o empréstimo no valor de 2.320 contos de réis a prazo de três anos. Em 1901, o Banque Belge de Préts Fonciers financiou a fazenda em 80 mil libras esterlinas no prazo de 9 anos. A companhia exportadora Prado Chaves realizou mais duas hipotecas em 1903 e 1905, somando 4.091 contos de réis. Por fim, ainda nesse último ano o Banco do Comércio e Indústria de São Paulo emprestou

${ }^{51}$ Não localizamos a aquisição dessa fazenda no $1^{\circ}$ Cartório de Imóveis de Ribeirão Preto. A compra por 70 contos de réis é informada por Darrel Levi (1977:167).

52 Esse banco foi aberto pela elite paulista em 1890, dentre eles Antonio da Silva Prado (cf. Levi 1977:248).

${ }^{53}$ Diário Oficial da União, 14 de abril de 1912: 4831-33.

54 Diário Oficial da União, 10 de abril de 1913:1622. Não localizamos o balanço de 1918 para facilitar a comparação com a Schmidt, mas em 1917 as dívidas em contas correntes não chegaram a representar três pontos porcentuais do passivo total (cf. O Estado de São Paulo, 24 de março de 1918:8).

55 A viúva Veridiana Prado e os filhos continuaram à frente da fazenda desde o falecimento do marido e pai em 1891. Não localizamos escrituras de compra ou venda de imóveis no cartório de Ribeirão Preto referente a essa propriedade. De acordo com a pesquisa de Levi, a fazenda foi comprada em 1889 por 600 contos de réis. 
2.500 contos de réis ao prazo de três anos, como ocorreu com a Guatapará. As fontes de financiamento das fazendas da família Prado eram bastante diversas, abarcando bancos e casas exportadoras nacionais e estrangeiras. As relações pessoais e familiares facilitavam a obtenção dos empréstimos, como na casa exportadora e mesmo no banco paulista. Assim, a fazenda compreendia, em 1904-05, quatorze mil alqueires de terras e 1.268 mil pés de café.

A partir dessa fazenda foi constituída a Companhia Agrícola Fazenda São Martinho em 1907. O capital da empresa foi de 5 mil contos de réis, declarando apenas a dívida com o banco Comércio e Indústria. Já em 1908, a companhia registrou sua primeira hipoteca em Sertãozinho, renovando o empréstimo com o Banco do Comércio e Indústria de São Paulo no mesmo valor a um prazo de quatro anos e a uma taxa de juros de $8 \%$. Ao final de 1911, houve novamente um financiamento com esse banco, totalizando 3 mil contos. Por fim, em 1914, registrou-se a última hipoteca com esse banco, perfazendo 5 mil contos ao prazo de 3 anos e juros de $9 \%$ ao ano. No balanço de 1918, a companhia declarou dívidas hipotecárias no valor 4.800 contos de réis, que perfazia $44,6 \%$ do passivo total. As demais dívidas eram muito reduzidas, como com colonos, empregados e contas correntes. ${ }^{56} \mathrm{O}$ grau de financiamento da empresa revelou-se intermediário relativamente às demais analisadas.

Outra sociedade anônima organizada foi a Companhia Agrícola do Ribeirão Preto em 1891, com sede social no Rio de Janeiro e capital de 8 mil contos de réis. Esse capital foi integralizado pela casa comissária carioca Buarque \& Cia pela entrega de propriedades agrícolas, ficando credor ainda da companhia em 2.264 contos. O médico Ernesto Torres Cotrim, de Ribeirão Preto, também integralizou 440 contos por meio de propriedade agrícola. Desse modo, não houve aquisição em dinheiro de imóveis, mas por meio de troca por ações. ${ }^{57}$ Houve diversas alterações societárias, passando a família Arruda Botelho a controlar a companhia em 1895, mudando a sede social para São Paulo. ${ }^{58}$ Nessa transferência, os administradores declararam a existência de um passivo constituído pelos portadores de debêntures e

${ }^{56}$ Diário Oficial de São Paulo, 13 de abril de 1919:2503.

57 Ainda havia capital a integralizar no balanço de 1902 (cf. Diário Oficial de São Paulo, 22 de agosto de 1902:1793).

${ }^{58}$ Segundo Kandas: "a Companhia pertenceu quase sempre, a um grupo familiar. Na primeira fase, de 1891 a 1894, inclusive, esteve em mãos de Buarque Macedo-Almeida e na fase final, Arruda Botelho, dos quais o conde e condessa do Pinhal foram os principais representantes." (1977:45). De acordo com o Ribeiro \& Campos (2012:68) o valor pago pelos Arruda Botelho para adquirir a companhia chegou a 5.410 contos de réis. 
pelos bônus do Banco da República do Brasil no valor de dois mil contos de réis, decorrente de uma hipoteca de 1894.

A companhia já tinha realizado uma hipoteca em 1891, por meio de debêntures em ouro e em papel no prazo de vinte e sete anos intermediado pelo Banco de Crédito Móvel. ${ }^{59}$ A outra hipoteca de 1899 foi a reafirmação das debêntures lançadas anteriormente pelo banco, mas por banqueiros franceses, ainda existindo 1.659 debêntures a 20 libras. ${ }^{60}$ No início do século $\mathrm{XX}$, a companhia foi descrita como possuidora de 2,5 milhões de pés de café e cerca de seis mil hectares. ${ }^{61}$ Por fim, a companhia realizou outra hipoteca em 1907 no valor de 400 contos de réis com industriais paulistanos. Desde essa época, não houve mais empréstimos bancários anotados em seus balanços até 1915. Destarte, o financiamento da companhia mostrou-se mais reduzido em relação aos anteriores. Essas companhias utilizaram-se de diferentes formas de financiamentos interno e externo, por meio de distintos instrumentos hipotecas e debêntures e atores como bancos, casas exportadoras ou particulares.

Outros grandes fazendeiros não constituíram companhia, mas também se destacaram em termos de empréstimos hipotecários. Elisário Ferreira de Camargo Andrade efetuou quatro hipotecas, totalizando dois mil e quinhentos contos de réis entre 1902 e 1907. Dentre os credores estão a Theodor Wille e Banque Belge de Préts Fonciers, somando 70 mil libras e respondendo por mais da metade dos financiamentos. No censo de 190405, esse proprietário mantinha 767 mil pés de café. Ademais, cinco cafeicultores detinham pouco mais de seiscentos mil pés de café em 1904-05: Manoel Maximiano Junqueira, Iria Alves Ferreira, Francisco Maximiano Junqueira, Joaquim da Cunha Diniz Junqueira e Joaquim Firmino D. Junqueira. Destes, os quatro primeiros realizaram, respectivamente, duas hipotecas (totalizando 818 contos), duas (476), uma (250) e duas (509). Para o último, não localizamos nenhuma hipoteca. ${ }^{62}$ Por fim, Francisca

${ }^{59} \mathrm{Em}$ 1894, houve a citação dos portadores das debêntures para receber uma quota referente ao resgate dos títulos. Nesse momento, a totalidade das debêntures era de 2.752 obrigações ouro e 1.311 obrigações em papel. O preço estipulado foi de $160 \$ 000$ réis pela de ouro e $140 \$ 000$ pela em papel, que tinha sido lançada por $200 \$ 000$. No conjunto do resgate, a soma chegaria a pouco mais de seiscentos contos de réis (cf. Diário Oficial da União, 1 de abril de 1894:991).

${ }^{60}$ No relatório da companhia de 1902, continuavam a resgatar as debêntures em ouro no seu devido tempo, num total de 48 nesse ano. O total lançado no balanço ainda era de 1.397 nesse momento, havendo ainda 700 em papel. No balanço de 1915, ainda constavam 253 debêntures ouro e 700 em papel (cf. Diário Oficial de São Paulo, 16 de abril de 1916:1612).

61 Ribeiro \& Campos (2012:68).

62 Provavelmente, trata-se de Joaquim Firmino de Andrade Junqueira, que realizou 4 hipotecas e pouco mais de mil contos de financiamentos entre 1903 e 1914. 
Silveira do Val não apresentou hipoteca no período em estudo, apesar de manter quase um milhão de pés de café em 1904-05. Embora nem todos os grandes cafeicultores tivessem dívidas hipotecárias e o grau de endividamento diferisse significativamente entre eles, uma ampla parcela dos cafezais e das terras do município foi utilizada em garantia de empréstimos de forma continuada no período em estudo. Assim, o financiamento hipotecário auxiliou a formação das unidades produtivas cafeeiras, principalmente as de grande porte.

\section{Credores: bancos e casas exportadoras}

A moradia dos credores revelou-se mais diversificada do que para os devedores. Primeiro, em termos do número de hipotecas, a sua grande maioria também residia em Ribeirão Preto (68,5\%), porém havia parcelas mais significativas para o interior de São Paulo e a capital, representando pouco mais de um décimo cada. Santos representava pouco mais um vigésimo do total das hipotecas $(5,7 \%)$. O Rio de Janeiro e países estrangeiros corresponderam a tão-somente 2,0\% e 1,3\% do número de hipotecas. Quando observamos os valores, o quadro modificou-se mais expressivamente. Santos e a capital paulista representaram os principais credores, totalizando $29,4 \%$ e $28,5 \%$, respectivamente. ${ }^{63}$ Ribeirão representou menos de um quinto (17,9\%). O interior de São Paulo, a praça carioca e o exterior respondiam, respectivamente, por $8,1 \%, 7,1 \%$ e $8,7 \%$. O maior valor médio das hipotecas era das dos credores estrangeiros e de Santos, atingindo pouco mais de 361 contos de réis e 279 , respectivamente. Desse modo, o grosso dos recursos foi mobilizado dentro do próprio estado de São Paulo, embora, como veremos adiante, companhias de capital estrangeiro operassem no Estado, como casas exportadoras e bancos.

As companhias credoras correspondiam a uma parcela pequena do número de hipotecas $(12,5 \%)$, porém movimentavam grande parcela das quantias transacionadas $(56,6 \%)$. Essas empresas mantinham uma presença bastante expressiva nesse mercado. Considerando o número de hipotecas, as profissões dos credores concentraram-se nos lavradores ou fazendeiros $(30,5 \%)$, negociantes $(24,8 \%)$, proprietários $(19,5 \%)$, capitalistas $(9,2 \%)$ e bancos

${ }^{63}$ Se observamos o número de hipotecas, Santos representou apenas um vigésimo do total (5,7\%). 
$(3,7 \%)$. Contudo, em termos dos valores, os negociantes destacaram-se, perfazendo quase quatro décimos $(38,5 \%)$. Os bancos e lavradores ou fazendeiros representaram parcelas próximas $(18,3 \%$ e 15,2\%). Por fim, os capitalistas e proprietários detinham menos de um décimo do total $(6,7 \%$ e $5,9 \%)$. Os bancos e capitalistas não eram os credores mais importantes como ocorria na capital paulista, depois dos proprietários.

Os negociantes formavam um grupo muito diversificado de pessoas físicas e jurídicas, compreendendo desde comerciantes, comissários a firmas comerciais. As casas exportadoras estabelecidas em Santos ou na capital paulista destacavam-se pelos grandes valores emprestados. O principal credor foi a firma alemã Theodor Wille \& Cia, que emprestou, em apenas dezesseis hipotecas, quase quatro décimos do total dos negociantes em todo o período $(39,7 \%) .{ }^{64}$ Os juros médios foram de cerca de $10 \%$ ao ano e o prazo médio de quase quatro anos. Os devedores eram grandes fazendeiros e companhias agrícolas, como Francisco Schmidt (55,9\% das hipotecas da companhia em Ribeirão), Arthur de Aguiar Diederichsen $(28,6 \%)$ e a família Prado (10,2\%). Uma rede de financiamento e comercialização de origem alemã, favorecendo a participação dos nacionais ou descendentes. ${ }^{65}$

A casa exportadora Prado Chaves \& Cia realizou sete hipotecas de 1895 a 1910. Os devedores eram principalmente fazendeiros, mas parentes dos controladores da companhia: três de Veridiana Valéria da Silva Prado (São Martinho) e duas de Fernando Pacheco Chaves (Santa Lydia). Os montantes emprestados somaram 7,8\% do total dos negociantes, alcançado o prazo médio de pouco mais de três anos e juros ao redor de 12\% ao ano. Assim, a maior parte dos empréstimos mantinha um caráter familiar, formando uma rede apoio mútuo envolvendo diferentes instituições (casas comerciais e bancárias).

${ }^{64}$ Outra casa exportadora de origem alemã foi a Zerrenner, Bullow \& Cia, que realizou quatro hipotecas no período compreendendo apenas $1,9 \%$ do total dos negociantes.

${ }^{65}$ Membros da família Diederichsen trabalhavam na companhia Theodor Wille, bem como Arthur na filial de São Paulo. De acordo com Melo Moraes, a empresa "tomou parte ativa e direta no desenvolvimento da lavoura cafeeira na região de Ribeirão Preto. Financiou a compra de muitas fazendas de café e, durante vários anos, forneceu o custeio para as mesmas." (1988:102). O entrelaçamento dos negócios era comum: "Durante muitos anos a Theodor Wille \& Cia. forneceu o custeio para as fazendas de Arthur Diederichsen e Francisco Schmidt, principais clientes da firma. A esses tinha que se somar diversos outros fregueses e as próprias fazendas da firma, o que representava um investimento considerável. Arthur Diederichsen ocupava o cargo de administrador geral de todas as fazendas de Wille" (idem:05). Segundo relato de seu funcionário Uebele: "recebeu durante muitos anos entre 250.000 e 300.000 sacas anualmente, ou 15 a 18 mil toneladas deste produto precioso da zona de Ribeirão Preto, em consignação" (Apud Moraes:106-107). 
Outra casa exportadora, importadora e financeira também se destacou: Société Financiére et Commerciale Franco Brésilienne, estabelecida em Paris e autorizada a funcionar no Brasil em 1907. A grande diferença foi o destino dos seus quatro financiamentos, concentrados em empreendimentos mais urbanos e de grande participação de equipamentos importados, como a Empresa de Força e Luz de Ribeirão Preto e Estrada de Ferro São Paulo e Minas em 1912 e 1907, respectivamente. ${ }^{66}$ Esses empréstimos responderam por $4,5 \%$ dos de todos os negociantes, por um prazo médio de quase quatro anos e juros médio de $11 \%$. Destarte, os empréstimos dessas casas exportadoras e importadoras revelaram-se muito distintos dos demais negociantes.

Os 26 bancos atuantes em hipotecas no município de Ribeirão Preto nesse período realizaram pouco mais de uma centena de hipotecas e movimentaram mais de 33 mil contos de réis, como pode ser observado na Tabela 1 abaixo. Não obstante os valores médios serem muito substantivos, havia grande disparidade entre as instituições financeiras. A partir de 1882, quatro bancos destacaram-se nas duas décadas seguintes: Crédito Real de São Paulo (17 hipotecas), União de São Paulo (17), do Brasil (15) e de Ribeirão Preto (13). Eles compreenderam um montante negociado de pouco menos de um quarto dos valores financiados $(23,5 \%)$. Os prazos e juros médios mostraram-se bastante favoráveis nesse momento por essas três primeiras instituições, superando os cem meses e $6 \%$ a $7 \%$ ao ano. ${ }^{67}$ Por fim, o banco da cidade emprestava a prazos menores e juros maiores.

${ }^{66}$ A empresa de Força e Luz realizou outra hipoteca para garantir um empréstimo de debêntures (ver Deminice 2015:121). Tosi, Faleiros e Fontanari ressaltam o financiamento dessa sociedade francesa ao Banco de Crédito Real de São Paulo em 1909, garantida por duas fazendas em Casa Branca (2011:410-411).

${ }^{67}$ Um caso distinto dos demais foi o do Banco Comercial Paulista, pois apresenta um prazo muito curto e juros mais elevados entre todos os bancos. 
Tabela 1 - Hipotecas de bancos em Ribeirão Preto (1882-1914)

\begin{tabular}{lcccccc}
\hline Bancos & № & Valor real & $\%$ & $\begin{array}{c}\text { Prazo } \\
\text { médio }\end{array}$ & $\begin{array}{c}\text { Juro } \\
\text { médio }\end{array}$ & $\begin{array}{c}\text { Ano da } \\
\text { primeira }\end{array}$ \\
\hline Banco Comercial Paulista & 1 & 36.366 .281 & $0,1 \%$ & 2,0 & 18,0 & 1899 \\
Banco Constructor e Agrícola de São Paulo & 9 & 1.849 .126 .622 & $5,6 \%$ & 153,3 & 12,4 & 1890 \\
Banco Construtor e Auxiliar de Ribeirão Preto & 3 & 214.552 .144 & $0,6 \%$ & 18,9 & 9,0 & 1892 \\
Banco da Lavoura & 2 & 37.607 .187 & $0,1 \%$ & 30,0 & 10,0 & 1888 \\
Banco da Republica do Brasil & 1 & 1.849 .517 & $0,0 \%$ & 120,3 & 7,0 & 1894 \\
Banco de Crédito Hypothecario e AESP. & 4 & 576.202 .621 & $1,7 \%$ & 102,0 & 9,5 & 1910 \\
Banco de Credito Móvel & 2 & 523.398 .128 & $1,6 \%$ & 255,5 & 6,5 & 1891 \\
Banco de Crédito Real & 1 & 312.723 .374 & $0,9 \%$ & 72,0 & 8,0 & 1888 \\
Banco de Credito Real de São Paulo & 17 & 1.884 .398 .235 & $5,7 \%$ & 135,8 & 7,3 & 1883 \\
Banco de Custeio Rural de Ribeirão Preto & 1 & 5.338 .458 & $0,0 \%$ & 36,0 & 2,0 & 1911 \\
Banco de Ribeirão Preto & 14 & 1.537 .534 .148 & $4,6 \%$ & 18,0 & 10,2 & 1895 \\
Banco de São Paulo & 5 & 690.039 .037 & $2,1 \%$ & 17,8 & 9,2 & 1899 \\
Banco do Brasil & 15 & 1.531 .912 .635 & $4,6 \%$ & 104,4 & 6,0 & 1882 \\
Banco do Comércio e Indústria de São Paulo & 6 & 16.587 .913 .480 & $50,1 \%$ & 50,0 & 8,5 & 1905 \\
Banco Industrial Amparense & 1 & 27.642 .127 & $0,1 \%$ & 12,0 & 15,0 & 1895 \\
Banco Melhoramentos do Jaú & 1 & 18.334 .086 & $0,1 \%$ & 24,0 & 10,0 & 1906 \\
Banco Mercantil de Santos & 5 & 405.317 .954 & $1,2 \%$ & 17,5 & 7,5 & 1895 \\
Banco Nacional Brasileiro & 2 & 201.017 .824 & $0,6 \%$ & 150,0 & 11,0 & 1900 \\
Banco União de São Paulo & 17 & 2.819 .505 .091 & $8,5 \%$ & 208,2 & 6,0 & 1890 \\
Dumont \& Companhia & 1 & 66.538 .518 & $0,2 \%$ & 12,0 & & 1897 \\
Banque Belge de Préts Fonciers & 7 & 3.185 .764 .907 & $9,6 \%$ & 121,0 & 8,0 & 1901 \\
Banque Brasilienne Italo Belge & 1 & 85.415 .332 & $0,3 \%$ & 60,0 & 0,0 & 1911 \\
Banque d'Anvers & 1 & 218.772 .265 & $0,7 \%$ & 36,0 & 10,0 & 1898 \\
Banque Française du Brésil & 1 & 70.736 .366 & $0,2 \%$ & 5,5 & & 1898 \\
London and Brazilian Bank Limited & 2 & 156.934 .134 & $0,5 \%$ & 24,0 & 8,0 & 1908 \\
Banca Francese e Italiana per L'America Sul & 1 & 50.000 .000 & $0,2 \%$ & 10,0 & 12,0 & 1914 \\
& & & & & & \\
\hline TOTAL & 120 & 33.094 .940 .471 & $100,0 \%$ & 75,2 & 7,9 & - \\
\hline & & & & & &
\end{tabular}

Obs.: Houve um caso em conjunto do Banco Mercantil de Santos, Banco Ribeirão Preto e herdeiros, que consideramos na tabela como do primeiro banco. Prazos em meses e juros ao ano.

No início do século XX, houve uma retração das negociações de hipotecas pelos bancos, refletindo a crise financeira daquela época. Poucas instituições atuaram nesse período de 1901 a 1914, somando 28 hipotecas. A partir de 1905, o Banco do Comércio e Indústria de São Paulo transacionou cinco hipotecas na região apenas para membros da família Prado e suas companhias, porém responderam por metade dos montantes transacionados pelos bancos em todo período $(50,1 \%)$. As relações familiares entre 
tomadores e credores facilitaram os grandes montantes emprestados, minimizando os riscos do negócio. ${ }^{68}$

Os bancos estrangeiros efetuaram apenas treze hipotecas, mas responderam por pouco mais de um décimo dos empréstimos hipotecários das instituições bancárias $(11,4 \%){ }^{69}$ Além deles, o Banco de Crédito Hypothecario e Agrícola do Estado de São Paulo, criado em 1909, e de capital francês, fez quatro empréstimos, mas respondeu por somente 1,7\% dos negócios bancários. Destarte, os bancos nacionais mantiveram-se mais relevantes no fornecimento do crédito hipotecário em Ribeirão, mesmo se levarmos em conta o banco de Crédito Hypothecario como francês.

Se onsiderarmos os bancos do exterior e os de capital estrangeiro, bem como a Theodor Wille e Zerrener e Bulow e Cia como empresas estrangeiras, a participação dessas companhias não se revelou expressiva no conjunto dos credores hipotecários, representando um quinto do total negociado no período $(20,1 \%)$. Se adicionarmos as pessoas físicas estrangeiras, o porcentual elevou-se a pouco menos de três décimos do conjunto $(29,4 \%)$. O crédito para as fazendas de café em Ribeirão Preto ocorreu principalmente entre agentes nacionais, particularmente dentro da província paulista. Contudo, os grandes fazendeiros apoiaram-se mais no capital estrangeiro, especialmente das casas exportadoras, em condições muitas vezes mais vantajosas.

\section{Considerações Finais}

A vasta estrutura produtiva cafeeira montada em Ribeirão Preto contou com o apoio de grandes volumes de crédito hipotecário no último quartel do século XIX e início do XX. Larga parcela dos cafezais encontrava-se hipotecada nessa época. Os montantes negociados em hipotecas superavam as transações imobiliárias do município, ao contrário do ocorrido na capital paulista. As quantias transacionadas em Ribeirão representaram uma parcela significativa da paulistana. Os juros dos dois municípios correlacionaram-se, salientando a arbitragem dos mercados e sua integração.

${ }^{68}$ Essa prática bancária aproxima-se do verificado por Naomi Lammoreaux para a Nova Inglaterra, emprestando por meio de redes de parentesco e favorecendo o desenvolvimento industrial (1996).

${ }^{69} \mathrm{O}$ Banque Belge de Prêts Fonciers foi a principal instituição estrangeira no período. 
Essa relação não ocorreu para o prazo, mas os patamares mostraram-se próximos na maior parte do período em estudo.

Os devedores eram principalmente agricultores centrados na atividade cafeeira. Grandes cafeicultores ou companhias agrícolas mantinham dívidas expressivas, apesar de alguns conseguirem evitar ou apresentar pouco endividamento. Esses empreendimentos compreenderam milhares de alqueires e milhões de pés de café, representando parcela expressiva do conjunto das hipotecas realizadas. As companhias agrícolas utilizaram-se não apenas de hipotecas, mas também de debêntures, penhores, ações, até mesmo colocadas em Londres, como a companhia Dumont. O crédito em particular hipotecário alavancou a formação das grandes unidades produtivas cafeeiras.

Diferentes agentes forneceram crédito para os proprietários dos cafezais, desde negociantes, lavradores e bancos. Apesar dos grandes valores hipotecados, a maior parte dos financiamentos originou-se de pessoas e empresas nacionais, não obstante a importância das casas exportadoras estrangeiras situadas em Santos e mesmo dos bancos estrangeiros e do capital externo. As redes de crédito estabelecidas favoreceram grandes devedores com ligação pessoal, familiar ou de nacionalidade com seus credores, sejam nacionais ou mesmo estrangeiros. As conexões pessoais e familiares facilitavam as operações de crédito efetivadas, até mesmo quando envolviam bancos.

O financiamento hipotecário foi parte fundamental da expansão cafeeira em Ribeirão Preto, mobilizando recursos de diferentes agentes, formas e origens, mas principalmente nacionais. Os volumes de hipotecas e de café nessa área alcançaram patamares extraordinários, negociando milhares de contos de réis e, posteriormente, produzindo milhões de arrobas de café anualmente. Se imaginarmos que outros instrumentos de crédito foram empregados, como penhor, letras, notas promissórias, empréstimos em conta corrente etc., o papel das finanças foi ainda maior do que o verificado nessa pesquisa por meio da hipoteca. O grande rush cafeeiro e a escala das propriedades geraram uma demanda por crédito em montantes muito expressivos, destacando a participação dos estabelecimentos de elevado porte na produção de café. De outro lado, os empréstimos viabilizaram os grandes investimentos cafeeiros e o acelerado crescimento das safras. 


\section{Referências}

Bacellar, Carlos Almeida Prado e Lucila Reis Brioschi. 1999. "Na Estrada do Anhanguera: uma visão regional da história paulista". São Paulo: Humanitas/CERU.

Bill, Albert e Paul Henderson. 2002. "South America and the First World War". Cambridge: Cambridge University Press.

Camargo, José Francisco. 1952. "Crescimento da população no Estado de São Paulo e seus aspectos econômicos: ensaio sobre relações entre a demografia e a economia". São Paulo: FFLCH/USP, v.3.

Colistete, Renato P. e Maria Lúcia Lamounier. 2014. "Land inequality in a coffee economy: São Paulo during the early twentieth century". São Paulo: Departamento de Economia - FEA/USP, no 2014-1.

Deminice, Daniel. 2015. "A arte de se construir cidades em meio à política local: Ribeirão Preto, 1890-1960". Dissertação (Mestrado em Arquitetura e Urbanismo) - IAU/USP.

Faleiros, Rogério Naques. 2014. “Major Claudiano \& família: o empobrecimento e o descrédito como elementos para a compreensão dos negócios no complexo cafeeiro (1893-1909)". Locus: revista de história 20(2):77-96.

Fontanari, Rodrigo. 2012. "O problema do financiamento: uma análise histórica sobre o crédito no complexo cafeeiro paulista: Casa Branca (1874-1914)”. São Paulo: Cultura Acadêmica.

2016. "Um banqueiro do café: a trajetória empresarial do Coronel Christiano Osório de Oliveira

e as teias do crédito na economia cafeeira paulista (1890 - 1937)". Tese (Doutorado em História) - FFLCH/USP.

Forner, Larissa Aparecida. 2017. "Francisco Schmidt: o colono que se tornou o 'Rei do Café' (1890-1924)". Dissertação (Mestrado em História Econômica) - FFLCH/USP.

Hanley, Anne G. 2005. "Native capital: financial institutions and economic development in São Paulo, Brazil, 1850-1920". Stanford: Stanford University Press.

Holloway, Thomas H. 1984. "Imigrantes para o café: café e sociedade em São Paulo,1886-1934”. Rio de Janeiro: Paz \& Terra.

IBGE. 1990. "Estatísticas históricas do Brasil: séries econômicas, demográficas e sociais de 1550 a 1988”. Rio de Janeiro: Fundação IBGE.

Kandas, Esther. 1977. "A instituição da companhia agrícola do "Ribeirão Preto" (1891-1895)". Dissertação (Mestrado em História) - FFLCH/USP.

Laerne, C. F. Van Delden. 1885. "Brazil and Java: report on coffee-culture in America, Asia and Africa". London: W. H. Allen.

Lavaez, Marina Pimentel. 2017. "Penhor e café em Ribeirão Preto (1894-1918)”. Monografia (Graduação em Economia) - FEA-RP/USP.

Levi, Darrel. 1977. A família Prado. São Paulo: Cultura 70.

Lopes, Luciana Suarez. 2005. "Sob os olhos de São Sebastião: a cafeicultura e as mutações da riqueza em Ribeirão Preto, 1849-1900". Tese (Doutorado em História) - FFLCH/USP.

Marcondes, Renato Leite. 2002. "O Financiamento hipotecário da cafeicultura no Vale do Paraíba (1865-87)". Revista Brasileira Economia 56(1): 147-170, jan./mar.

Milliet, Sérgio. 1939. "Roteiro do Café e outros ensaios". São Paulo: Departamento de Cultura.

Monbeig, Pierre. 1984. "Pioneiros e fazendeiros de São Paulo”. São Paulo: Editora HUCITEC/POLIS.

Moraes, Maria Luiza de Paiva Melo. 1980. "Companhia Agrícola Francisco Schmidt: origem, formação e desintegração (1890-1924)”. Dissertação (Mestrado em História Social) - FFCLH/USP.

Moraes, Maria Luiza de Paiva Melo. 1988. "A atuação da firma Theodor Wille \& Cia. no mercado cafeeiro no Brasil: 1844-1918”. Tese (Doutorado em História) - FFLCH/USP.

Motta, José Flávio \& Nozoe, Nelson Hideiki. 1994. "Cafeicultura e Acumulação”. Estudos Econômicos 24(2): 253-320. 
Peláez, Carlos Manuel; Suzigan, Wilson. 1981. "História Monetária do Brasil: análise da política, comportamento e instituições monetárias”. $2^{\mathrm{a}}$ ed. Brasília: Universidade de Brasília.

Piñeiro, Théo Lobarinhas. 2007. "A carteira hipotecária do Banco do Brasil: os conflitos em torno do crédito agrícola no II Reinado". Guimarães, Elione Silva \& Motta, Márcia Maria Menedes (orgs.). Campos em disputa: história agrária e companhia. São Paulo: Annablume, 41-62.

Pires, Anderson. 2009. “Café, finanças e indústria: Juiz de Fora, 1889-1930”. Juiz de Fora: Funalfa.

Ribeiro, Maria Alice Rosa. 2015. "Riqueza e endividamento na economia de plantation açucareira e cafeeira: a família Teixeira Vilela-Teixeira Nogueira". Campinas, São Paulo, século XIX. Estudos Econômicos 45(3): 527-565, jul./set..

Ribeiro, Maria Alice Rosa \& Cristina de Campos. 2012. "História da riqueza na economia cafeeira paulista: a família Arruda Botelho (1854-1901)”. Resgate XX(24):59-73, jul./dez.

Saes, Flávio Azevedo Marques de. 1981. “As ferrovias de São Paulo (1870-1940)”. São Paulo: Hucitec.

Saes, Flávio Azevedo Marques de. 1986. "Crédito e bancos no desenvolvimento da economia paulista (18501930)". São Paulo: IPE/USP.

Stein, Stanley Julian. 1961. "Grandeza e decadência do café no vale do Paraíba”. São Paulo: Brasiliense.

Teodoro, Rodrigo da Silva. 2006. "O crédito no mundo dos senhores do café. Franca 1885-1914”. Dissertação (Mestrado em História Econômica) - IE/UNICAMP.

Tosi, Pedro Geraldo; Faleiros, Rogério Naques e Fontanari, Rodrigo. 2011. "Modalidades e hierarquias do crédito na cafeicultura paulista (1889-1930)". Revista Brasileira de Economia 65(4): 401-412, out./dez.

Sweigart, Joseph Earl. 1980. "Financing and marketing brazilian export agriculture: the coffee factors of Rio de Janeiro, 1850-1888”. Tese (Phd em História) - University of Texas.

Werneck, Luís Peixoto de Lacerda. 1857. "Estudos sobre o crédito rural e hipotecário seguidos de leis, estatutos e outros documentos". Rio de Janeiro: Casa de B. L. Garnier.

Zamboni, Silvio Perini. 1979. "O café no norte paulista: a crise de 1929 na fazenda Dumont". Piracicaba: Mestrado em Economia Agrária ESALQ/USP. 


\section{Apêndice Estatístico}

Valores, Juros e prazos negociados em hipotecas para Ribeirão Preto (1876-1914)

\begin{tabular}{|c|c|c|c|c|}
\hline Ano & Número & $\begin{array}{l}\text { Valor nominal } \\
\text { (em réis) }\end{array}$ & $\begin{array}{c}\text { Taxa anual } \\
\text { média de juros }\end{array}$ & $\begin{array}{l}\text { Prazo médio } \\
\text { (em meses) }\end{array}$ \\
\hline 1876 & 2 & 5.949 .248 & 21,0 & 12,0 \\
\hline 1877 & 1 & 11.200 .000 & 12,0 & 12,0 \\
\hline 1878 & 4 & 60.404 .000 & 13,5 & 17,0 \\
\hline 1879 & 10 & 117.072 .573 & 11,4 & 21,1 \\
\hline 1880 & 8 & 187.617 .735 & 13,9 & 23,7 \\
\hline 1881 & 16 & 308.904 .890 & 12,2 & 28,3 \\
\hline 1882 & 16 & 256.381 .515 & 10,9 & 34,9 \\
\hline 1883 & 20 & 350.254 .759 & 11,7 & 64,7 \\
\hline 1884 & 10 & 65.672 .190 & 15,4 & 52,7 \\
\hline 1885 & 9 & 97.796 .168 & 10,5 & 28,5 \\
\hline 1886 & 18 & 157.686 .892 & 14,4 & 24,7 \\
\hline 1887 & 25 & 240.315 .562 & 11,2 & 10,7 \\
\hline 1888 & 35 & 545.009 .825 & 11,8 & 18,9 \\
\hline 1889 & 57 & 1.303 .281 .604 & 11,2 & 28,0 \\
\hline 1890 & 95 & 3.959 .719 .434 & 10,8 & 76,7 \\
\hline 1891 & 86 & 4.038 .449 .610 & 11,4 & 44,7 \\
\hline 1892 & 69 & 1.712 .473 .750 & 12,1 & 20,9 \\
\hline 1893 & 80 & 1.566 .249 .243 & 15,9 & 16,5 \\
\hline 1894 & 68 & 1.183 .411 .620 & 15,2 & 21,8 \\
\hline 1895 & 96 & 11.817 .481 .424 & 13,6 & 23,4 \\
\hline 1896 & 144 & 26.526 .484 .598 & 15,5 & 24,6 \\
\hline 1897 & 199 & 6.907.910.779 & 18,5 & 18,6 \\
\hline 1898 & 223 & 11.122 .098 .261 & 17,5 & 21,4 \\
\hline 1899 & 210 & 11.438 .117 .592 & 14,6 & 29,4 \\
\hline 1900 & 152 & 8.944.829.361 & 14,6 & 28,6 \\
\hline 1901 & 125 & 13.788 .005 .966 & 14,0 & 24,6 \\
\hline 1902 & 117 & 3.594.652.795 & 13,5 & 24,5 \\
\hline 1903 & 107 & 6.234 .168 .839 & 13,9 & 30,1 \\
\hline 1904 & 103 & 5.406 .892 .076 & 12,8 & 29,8 \\
\hline 1905 & 90 & 6.913 .395 .038 & 14,1 & 24,8 \\
\hline 1906 & 84 & 5.007 .978 .948 & 14,2 & 26,5 \\
\hline 1907 & 111 & 4.891.941.827 & 13,9 & 30,0 \\
\hline 1908 & 109 & 4.508.307.159 & 14,5 & 25,1 \\
\hline 1909 & 132 & 2.756 .392 .394 & 13,8 & 29,3 \\
\hline 1910 & 133 & 8.674 .767 .204 & 13,1 & 34,1 \\
\hline 1911 & 116 & 8.011.949.818 & 12,1 & 30,9 \\
\hline 1912 & 111 & 17.108 .540 .760 & 10,8 & 29,8 \\
\hline 1913 & 142 & 5.194 .109 .670 & 12,8 & 26,7 \\
\hline 1914 & 217 & 10.636 .587 .846 & 14,2 & 24,2 \\
\hline Total & 3350 & 195.652 .462 .973 & 14,3 & 28,2 \\
\hline
\end{tabular}

